\title{
Lipid abundance and composition of a humic Oxisol as a function of land use
}

\author{
Cristiane Pereira de Assis ${ }^{1}$; Francisco Javier González-Vilaa; Ivo Jucksch ${ }^{3 *}$; Jose Antonio \\ González-Pérez²; Júlio César Lima Neves³; João Luis Lani³ ${ }^{3}$ Eduardo de Sá Mendonça ${ }^{3,4}$ \\ ${ }^{1}$ UNIVASF - Universidade Federal do Vale do São Francisco, Ceagro, Rod. BR 401, km 12 - $56300-000$ - \\ Petrolina, PE - Brasil. \\ ${ }^{2}$ IRNAS/CSIC - Inst. de Recursos Naturales de Sevilla, PO Box 1052 - 41012 - Sevilla, Spain. \\ ${ }^{3} U F V$ - Depto. de Ciência do Solo, Av. P.H. Rolfs, s/n - 36570-000 - Viçosa - MG, Brasil. \\ ${ }^{4}$ DPV/UFES - Depto. de Produção Vegetal - 29500-000 - Alegre, ES - Brasil. \\ *Corresponding author<ivo@ufv.br>
}

\begin{abstract}
Soil organic matter of a humic Oxisol has been characterized by analyzing litter and soil lipid composition under vegetal covers (coffee, pasture and fragment of native forest). Soil and litter samples were collected from each site at two depths (0-10 and 60-100 cm). Lipid composition was determined by gas chromatography-mass spectrometry (CG-MS). In the solvent extracts of the soil lipids, even-numbered nalkanoic acids in the range of $\mathrm{C}_{16}-\mathrm{C}_{32}$ indicate a soil organic matter input from higher plant waxes. The major compound classes in both the soil and the litter included saturated n-alkanoic acids, with average values in the total spectrum of 58 and $53 \%$, respectively Clear differences in lipid composition were found between the topsoil and subsurface. Long chain alkylic compounds (alkanoic acids and alkanes) accumulated preferably at depths of $60-100 \mathrm{~cm}$. On the surface, the soil from natural vegetation had a total lipid value higher than those cultivated soils, and showed a predominance of unsaturated alkanoic acids at $60-100 \mathrm{~cm}$. Preservation of alkylic moieties with depth was observed under forest and pasture, indicating that these systems of land use are prone to lipid accumulation. Lipids, especially the long-chain $\left(>\mathrm{C}_{20}\right)$ ones, may be important with regard to $\mathrm{C}$ stabilization and humification processes in subsoil of humic Oxisols, highlighting the importance of lipids compounds in the bulk structure of organic matter these soils.
\end{abstract}

Key words: soil and litter lipid, soil management, tropical soil, grass, coffee

\section{Abundância e composição de lipídios em Latossolo Húmico em função do uso do solo}

\begin{abstract}
RESUMO: A matéria orgânica de um Latossolo Húmico foi caracterizada por meio da análise da composição lipídica do solo e da serapilheira sob coberturas vegetais (café, pastagem e fragmento de mata nativa). Em cada área foram coletadas amostras de solo em duas profundidades $(0-10$ e 60-100 cm), assim como amostras da serapilheira. A composição lipídica foi determinada por cromatografia gasosa-espectroscopia de massa. No extrato lipídico do solo a ocorrência de ácidos alcanóicos com número par de carbonos $\left(\mathrm{C}_{16}-\mathrm{C}_{32}\right)$ indicou presença de cera de plantas superiores na composição da matéria orgânica do solo. Tanto no solo quanto na serapilheira a principal classe de compostos incluiu n-alcanóicos saturados, com valores médios de 58 e $53 \%$ do total do cromatograma, respectivamente. Clara diferença foi encontrada entre os extratos lipídicos obtidos na superfície e subsuperfície do solo. Compostos alquílicos de cadeia longa (ácidos alcanóicos e alcanos) acumularamse preferencialmente entre $60-100 \mathrm{~cm}$. Superficialmente, o solo sob vegetação natural apresentou maiores teores de lipídios totais que os solos cultivados, mostrando também predominância de ácidos alcanóicos insaturados entre 60-100 cm. Nas áreas sob mata e pastagem houve, em profundidade, preservação de alcanos de cadeia curta; evidenciando maior conservação dos mesmos nestes sistemas de uso da terra. Os lipídios, especialmente os de cadeia longa $(>20)$, podem ser muito importantes nos processos de estabilização e humificação do $C$ em camadas subsuperficiais de Latossolos Húmicos, ressaltando a importância dos compostos lipídicos na composição da matéria orgânica destes solos.

Palavras-chave: lípidios do solo e serapilheira, manejo do solo, solo tropical, pastagem, cafeicultura
\end{abstract}

\section{Introduction}

The influence of soil management systems on the contents and quality of soil organic matter (SOM) of subtropical Brazilian soil and, consequently, on the properties and the ability of the soil to promote carbon sta- bilization (sequestration) is a research subject of major interest. The general pattern of land use in the Zona da Mata Mineira region in the stete of Minas Gerais, Brazil, is coffee (Coffea arabica) cropping and pastures of molasses grass (Mellinis minutiflora) (Resende et al., 2002). Most of these cultivated areas are supported by 
humic Oxisols because of their great friability, permeability and water retention capacity (Ker, 1999). Furthermore, these clay reddish-orange soils are acidic and characterized by the presence of a darker A horizon with humic fraction enrichment and an average $\mathrm{C}$ stock of $30.2 \mathrm{~kg} \mathrm{~m}^{-2}$ (Andrade et al., 2004). The type of land use can affect the $\mathrm{C}$ stock in these soils, as well as the composition and quality of SOM added. Among the SOM fractions, lipids participate in the biogeochemical soil processes, as well as in the relationship between plants and their ecological environments (Quénéa et al., 2004; Jansen et al., 2006; Wiesenberg et al., 2006; Wiesenberg et al., 2008).

The lipids (alkanoic acids, alkanes, alkanols, ketones, wax esters, terpenoids, steroids, and phospholipids) are often described as organic compounds that are insoluble in water and soluble in organic solvents, with significant contribution in the aliphatic composition of SOM (Dinel et al., 1990; Stevenson 1994; Bull et al., 2000). In general, the accumulations of SOM rich in aliphatic compounds is linked to a high lipid input, particularly long-chain aliphatic compounds, mainly from vegetation, microbial activity and low soil $\mathrm{pH}$ (Bull et al., 2000).

The study of the composition of the total lipid extracts (TLEs) in both topsoil and subsoil layers may provide additional information about both compounds with value as plant-derived biomarkers of SOM sources and diagenesis products in the soil profile (Schulten and Schnitzer, 1990; Quénéa et al., 2004; Almendros et al., 2001; Jandl et al., 2007; Weisenberg et al., 2010). The soil lipid composition at the top layers in different agrosystems, may reflect the direct impact of the soil use mainly the influence of the plant litter or the entrance or preservation of organic contaminants (Weisenberg et al., 2006; Ahangar et al., 2009). Wiesenberg et al. (2010) observed changes in the soil lipid composition due to the vegetation change from green fallow ( $\mathrm{C}_{3}$ grass) to wheat $\left(\mathrm{C}_{3}\right.$ grass $)$ cropping in a Gleyic Cambisol after four years. In turn, Zelles et al. (1995) observed differences between fatty acids in grassland and cultivated soils when monounsaturated fatty acid fraction was evaluated, showing that it is possible to evaluate changes in the land use through soil lipid composition.

Gas chromatography-mass spectrometry (CG/MS) and analytical pyrolysis are two techniques used to lipids characterization in plant and soil. Several studies have used these techniques to assess the concentrations, distribution pattern, and turnover rates of these compounds in the soil (Jandl et al., 2004; Feng et al., 2010).

As far as we know, studies on the lipid composition in Brazilian tropical soil are still rare. In this paper, we studied TLEs of these soils with two aims: i) to assess the influence of agricultural management practices (coffee and pasture) on the lipid composition of top and deep soil layers; ii) to evaluate differences in lipid composition of topsoil and subsoil in the darker A horizons.

\section{Material and Methods}

The study was done in the Atlantic Forest Biome region at "Zona da Mata Mineira", Southeast Brazil (20²8'26" S, 42²8'55" W, average altitude of $712 \mathrm{~m}$ a.s.l.). The typical climate of the region is subtropical with rainy summers and dry winters. The mean annual rainfall and temperature are $1300 \mathrm{~mm}$ and $18^{\circ} \mathrm{C}$, respectively. The vegetation in the area can be classified as a Mountain Semideciduous Mesophytic forest (Semi-deciduous tropical forest) with emergent canopy (Fme) (IBGE, 1993).

The studied soil was described as a Typic Hapludox, clayey, dystrophic, and acid, with high content of exchangeable $\mathrm{Al}$ and organic matter. These soils are derived from migmatite rocks and are typical in the high altitude areas. For this study, three sites in the Zona da Mata Mineira with the typical pattern of land use (coffee, pasture, and forest) under the same taxonomic soil units and slope were sampled. The standard farming exploration when established at the beginning of the settling caused continuous deforestation, replacing the native tropical forest with cultures that became traditional in the region (coffee plantations and for other farming and pastures).

The soil under coffee has been cultivated for the last 12 years and the fertilization management consists of the addition of NPK (25-10-20) fertilizer twice a year and lime every two years. Before the coffee was established, the site was under pasture (Melinis minutiflora) during 40 years. The pasture sites were established in the $1940 \mathrm{~s}$ after slashing and burning the forest. However, after livestock market and low revenues in the 1960 s, a great part of this area was converted to coffee plantation. In the region the major area that once was devoted to pastures is now degraded and farmers keep only the cleared areas for cattle grazing, without much management. The molasses grass (Melinis minutiflora) predominates in the pasture, and the generalized occurrence of this grass is indicative of low-production acid soils. For comparative purposes, soil samples under the native forest ecosystem were also sampled and studied.

Soil sampling was carried out at the beginning of the wet season in the year 2005. Due to the polychrome presented by A horizon, composite soil samples were taken from superficial $(0-10 \mathrm{~cm})$ and sub-superficial $(60-100 \mathrm{~cm})$ depths. Three plots of $100 \mathrm{~m}^{2}$, each spaced $10 \mathrm{~m}$ apart, were sampled by boring five times each subplot with an auger. For each depth of each plot twenty sub-samples were collected and pooled. Soil samples were air dried at room temperature and sieved through a $2 \mathrm{~mm}$ mesh. The main physico-chemical characteristics of the soils are given in Table 1.

Litter samples were collected from the same subplots as the soil samples using a $0.25 \mathrm{~m}^{2}(0.5 \times 0.5 \mathrm{~m}) \mathrm{me}-$ tallic platform; four sub-samples collected in an area of circa $100 \mathrm{~m}^{2}$. For each plot the samples were thoroughly mixed to form a single sample, dried at $40^{\circ} \mathrm{C}$ in an oven, milled, weighed and analysed in triplicate. Litter $(2 \mathrm{~g})$ and soil $(20 \mathrm{~g})$ lipids were Soxhlet-extracted at approxi- 
mately $70^{\circ} \mathrm{C}$ for $16 \mathrm{~h}$, using $200 \mathrm{~mL}$ of the mixture dichloromethane/methanol $(3: 1 \mathrm{v} / \mathrm{v})$ (van Bergen et al., 1997). Total lipid content was gravimetrically estimated as percentage of dry soil. To discuss the data we used descriptive statistics, considering the standard errors of the mean. For the compound abundance we established the distribution patterns on the basis of the relative abundance of the compounds in the chromatograms.

The free lipids were methylated with trimethylsilyldiazomethane and silylated with $\mathrm{N}, \mathrm{O}$ bis(trimethylsilyl)-trifluoroacetamide (BSTFA) before analysis by gas chromatography-mass spectrometry (GCMS). Separation of lipids compounds was achieved using a SE-52 fused silica capillary column $(30 \mathrm{~m} \times 0.32$ $\mathrm{mm}$ i.d., film thickness $0.25 \mathrm{~m}$ ). The column oven temperature was programmed to increase from 40 to $100^{\circ} \mathrm{C}$ at $30^{\circ} \mathrm{C} \mathrm{m^{-1 }}$ and then to $300^{\circ} \mathrm{C}$ at $6^{\circ} \mathrm{C} \mathrm{min}^{-1}$. Helium was used as carrier gas at a flow rate of $1.5 \mathrm{~mL} \mathrm{~min}^{-1}$. Mass spectra were measured at $70 \mathrm{eV}$ ionizing energy. Individual compounds were identified by inspecting mass fragments, key single ion monitoring (SIM) for the different homologous series, by low resolution mass spectrometry and by comparison with published mass spectra and computerized libraries (NIST and Wiley).

\section{Results and Discussion}

Lipid contents ranged from 0.72 to $1.49 \mathrm{~g}{\text { ( } \mathrm{kg} \mathrm{soil})^{-1}}^{-1}$ for the topsoil $(0-10 \mathrm{~cm})$ and from 0.61 to $1.12 \mathrm{~g}(\mathrm{~kg} \text { soil })^{-1}$ for the subsoil $(60-100 \mathrm{~cm})$ (Figure 1-B). The decrease in the TLE with the increase in depth (Figure 1-B) has been observed by other researchers (Ziegler and Zech, 1989; Amblès et al., 1998; Naafs et al., 2004). The extracted lipids accounted for $2.2-5.7 \%$ of soil $C$, with an average value of $3.23 \%$. These lipid contents are consistent with the values suggested as typical by Stevenson (2004) (1.2 - 6.3\%) and Dinel et al. (1990) (4-8\%).

The total amounts of TLE was higher in the coffee litter in comparison to pasture and forest litter (Figure 1A). Although extractable soil lipids content was low under forest, it was higher than that found for the cultivated soils (Figure 1-B). Despite the relatively low values found for forest litter, the soil under forest has higher lipid content than cultivated soils. This result suggests the occur-

Table 1 - Average values for physico-chemical characteristics of two layers of the A horizon of the studied humic Oxisol under coffee, pasture and natural forest.

\begin{tabular}{|c|c|c|c|c|c|c|c|c|c|c|c|c|}
\hline Depth & $\begin{array}{c}\mathrm{pH} \\
\left(\mathrm{H}_{2} \mathrm{O}\right)\end{array}$ & $\mathrm{Mg}^{2+}$ & $\mathrm{Ca}^{2+}$ & $\mathrm{CEC}^{\mathrm{a}}$ & $\mathrm{Al}^{3+}$ & $\mathrm{H}+\mathrm{Al}$ & $\mathrm{TOC}^{\mathrm{c}}$ & $\mathrm{TN}^{\mathrm{d}}$ & $\mathrm{BD}^{\mathrm{e}}$ & Sand & Silt & Clay \\
\hline & & \multicolumn{5}{|c|}{$\mathrm{mmol}_{\mathrm{c}} \mathrm{dm}^{-3}$} & \multicolumn{2}{|c|}{$\%$} & $\mathrm{~g} \mathrm{~cm}^{-3}$ & \multicolumn{3}{|c|}{$\mathrm{g} \mathrm{kg}^{-1} \ldots$} \\
\hline \multicolumn{13}{|c|}{ Coffee } \\
\hline $0-10$ & 5.1 & 5.3 & 21.0 & 124.0 & 13.3 & 124.0 & 3.34 & 0.26 & 0.94 & \multirow{2}{*}{330} & \multirow{2}{*}{110} & \multirow{2}{*}{560} \\
\hline $60-100$ & 4.8 & 0.3 & 2.3 & 112.4 & 14.0 & 112.4 & 2.77 & 0.15 & 0.85 & & & \\
\hline \multicolumn{13}{|c|}{ Pasture } \\
\hline $0-10$ & 4.9 & $n d^{f}$ & 5.3 & 126.0 & 14.0 & 126.0 & 3.55 & 0.26 & 0.96 & \multirow{2}{*}{290} & \multirow{2}{*}{70} & \multirow{2}{*}{640} \\
\hline $60-100$ & 5.1 & nd & 1.3 & 110.3 & 7.3 & 110.3 & 3.03 & 0.18 & 0.80 & & & \\
\hline \multicolumn{13}{|c|}{ Forest } \\
\hline $0-10$ & 4.8 & nd & 0.6 & 117.0 & 1.0 & 115.5 & 2.61 & 0.27 & 1.05 & \multirow{2}{*}{330} & \multirow{2}{*}{110} & \multirow{2}{*}{560} \\
\hline $60-100$ & 5.0 & nd & nd & 102.4 & 12.0 & 102.3 & 2.67 & 0.21 & 0.86 & & & \\
\hline
\end{tabular}

${ }^{\mathrm{a}}$ Cation exchange capacity $(\mathrm{pH} 7.0) ;{ }^{\mathrm{b}} \mathrm{H}+\mathrm{Al}=$ potential acidity; ${ }^{\mathrm{c}} \mathrm{TOC}=$ total organic carbon; ${ }^{\mathrm{d}} \mathrm{TN}=$ total nitrogen; ${ }^{\mathrm{e}} \mathrm{BD}=\mathrm{Bulk}$ density; ${ }^{\text {fno }}$ detected.
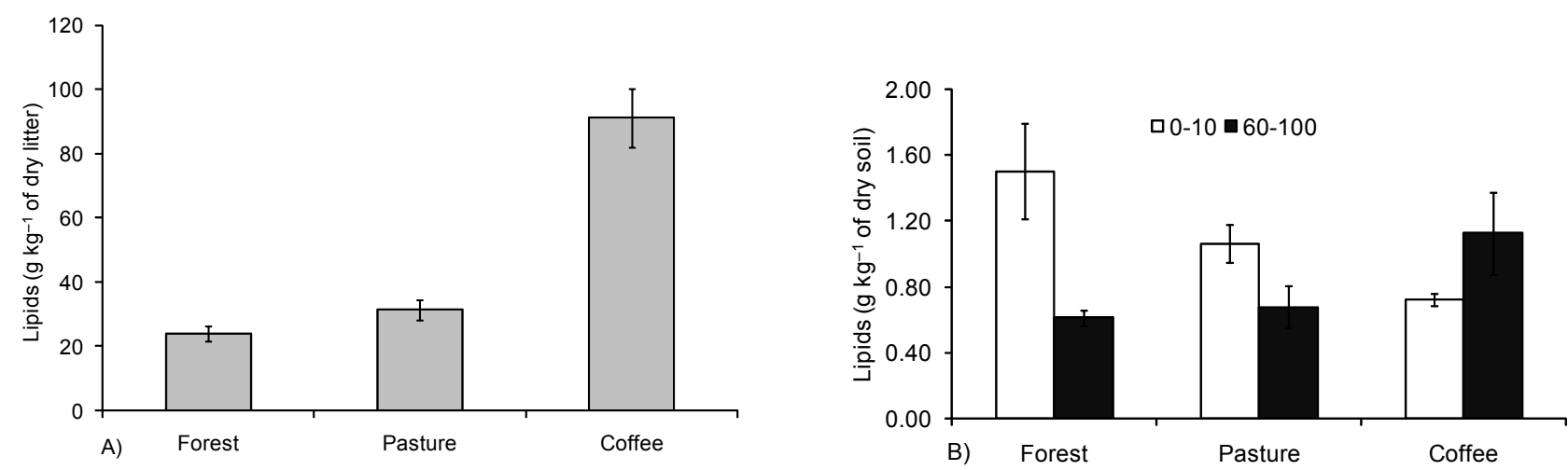

Figure 1 - Total lipid extracts from litter (A) and topsoil and subsoil (B) from humic Oxisol under coffee and pasture land use. 
rence of accumulation or preservation mechanisms in the soil. It is possible that the biomass production in areas under forest, pasture and coffee, measured in 6.8, 3.2 and $2.8 \mathrm{Mg} \mathrm{ha}^{-1}$, respectively (unpublished data), has favored the increase of lipid content in superficial soil layers in forest and pasture. Conversely, a higher lipid proportion in the deeper layers in soils under coffee may indicate that an important part of lipids from the litter is easily lixiviated along the soil profile (Nierop et al., 2005). In addition to possible lixiviation, the preservation of lipids at $60-100 \mathrm{~cm}$ in coffee may be favored by a low soil $\mathrm{pH}$ (4.8), as the acidic conditions can significantly inhibit the decomposition of lipid compounds (Dinel et al., 1990; Ziegler and Zech, 1989; Stevenson 1994).

Roots tissues (Nierop et al., 2005; Wiesenberg and Schawark, 2006; Jansen and Nierop, 2009) and aboveground biomass (Wiesenberg et al., 2010) have an important role in the soil lipid composition. Although in this study the contribution of root tissues could not be assessed, litter under forest can effectively contribute to topsoil lipid content, as compared to pasture and coffee uses. Soil lipids varied with the type of land use, more conservation systems (forest and pasture land use, respectively) presented increases in the soil lipid content. This increase in the lipid fraction will have a positive influence on the dynamics and stock of soil carbon.

Overall, saturated alkanoic acids were the most abundant class of compounds in the lipid soil fraction, with a dominance of long-chain over short chain compounds (Figure 2), as also found by several authors (Bull et al., 1998; Chefetz et al., 2002; Jandl et al., 2004; Quénéa et al., 2004). Alkanoic acids in soils may originate from plants and/or insects, oxidation of long chain alcanols, and leaching down the soil profile (Nierop et al., 2005).

A homologous series of satured alkanoic acids from $\mathrm{C}_{8}$ (octanoic acid) to $\mathrm{C}_{30}$ (triacontanoic acid) with a predominance of even numbered C-chain lengths, was observed both in the litter and soil extracts. Similar values were previously reported by Jandl et al. (2005) for Ap horizon of a Phaeozem with long-term cropping of rye and maize. The most abundant alkanoic acids in the soil samples, except the forest soil, were predominated by the ubiquitous $\mathrm{C}_{16}$ and even long chain alkanoic acids $\left(\mathrm{C}_{24}-\mathrm{C}_{30}\right)$. The chromatograms of the litter extracts showed maxima at $\mathrm{C}_{16}$ and $\mathrm{C}_{18}$. Their presence in the upper soil layer (Figure 2) is indicative of a direct contribution from the above vegetation (litter) to the soil lipid composition (Gleixner et al., 2001). In general, plant-derived signatures dominate our samples. In particular, unsaturated alkanoic acids $\left(\mathrm{C}_{18: 1}\right.$ and $\left.\mathrm{C}_{18: 2}\right)$ were most abundant in the litter and soil samples under forest (0$10 \mathrm{~cm}$ ). The presence of an unsaturated $C_{18: 1}$ in the forest topsoil reflect the contribution of relatively fresh material, and indicates low to moderate level of lipid degradation due to the more rapid degradation of the unsaturated compounds in soil (Moucawi et al., 1981; Weisenberg et al., 2010). These alkanoic acids can also be selectively preserved in the soil with little or no alteration (Almendros et al., 1996; Nierop et al., 2005) and preferentially preservation in the clay fractions (Quénéa et al., 2004). In contrast with the litter lipid composition, the soil alkanoic acids present a bimodal distribution in the range of $\mathrm{C}_{18}-\mathrm{C}_{30}$, which is more evident in the deeper layers $(60-100 \mathrm{~cm})$. Thus, compared to layers 0 $10 \mathrm{~cm}$ and $60-100 \mathrm{~cm}$, a larger amount of long chain fatty acids $\left(\mathrm{C}_{24}-\mathrm{C}_{30}\right)$ occurred in $60-100 \mathrm{~cm}$.
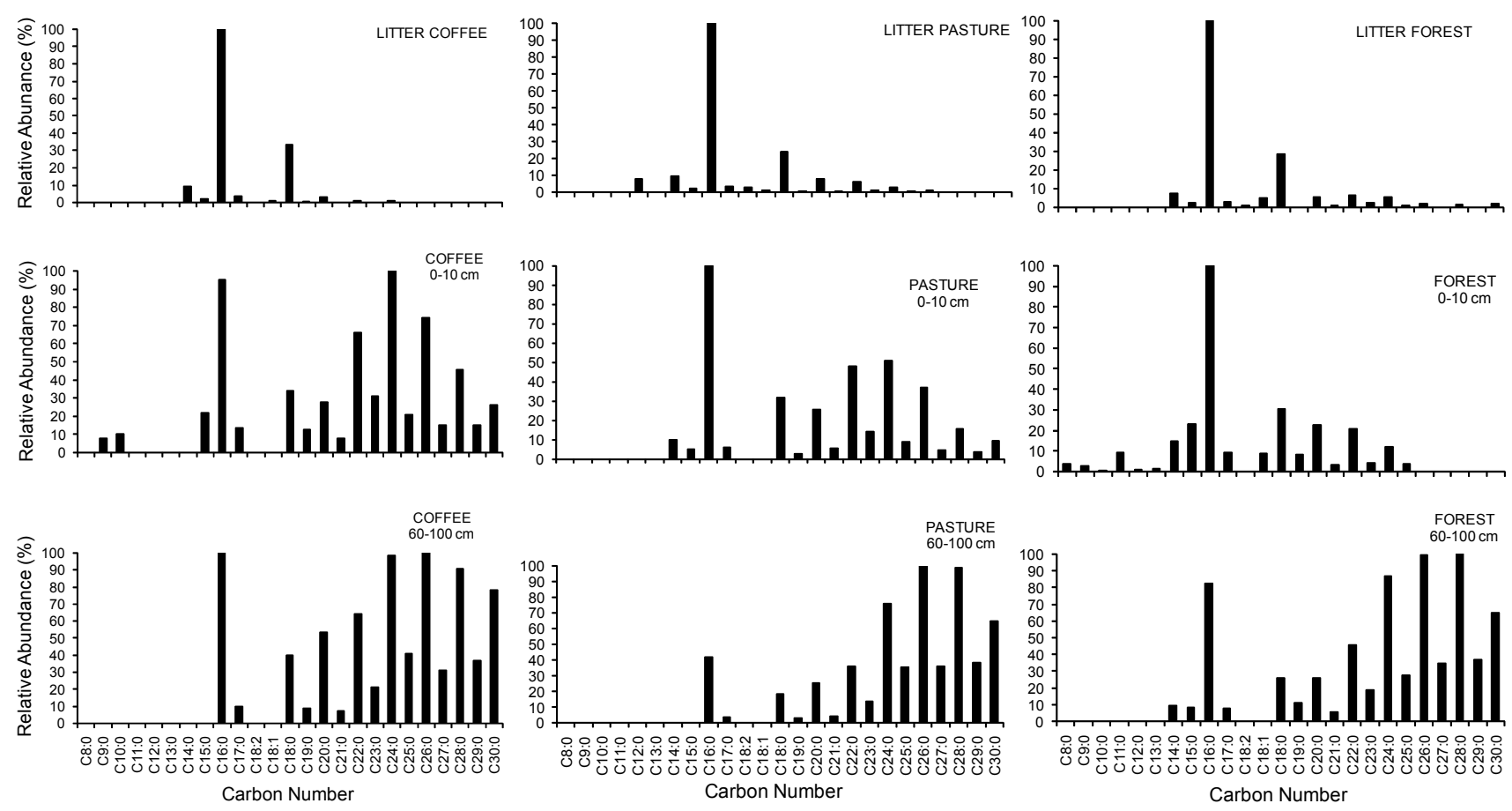

Figure 2 - Relative distributions of alkanoic acids extracted from litter and soils analysed, normalized to the most abundant compound. 
Short chain $\left(\mathrm{C}_{15}\right.$ and $\left.\mathrm{C}_{17}\right)$ fatty acids were observed both in the litter and the surface soil layers $(0-10 \mathrm{~cm})$. The occurrence of short chain alkanoic acids in the 60$100 \mathrm{~cm}$ depth under forest suggests higher microbial activity under this land use system, the presence of these compounds being associated with biomarkers of bacterial origin (Vestal and White, 1989; Jansen et al., 2006; Jandl et al., 2007). The litter from Coffea arabica was characterized by higher proportions $(66.36 \%)$ of saturated alkanoic acids relative to the unsaturated compounds $(11.42 \%)$. The lower ratio of long-chain versus shortchain alkanoic acids with depth is explained by the selective degradation of short-chain homologues (Tan, 2003; Jandl et al., 2005). The increase in this ratio reflects differential contributions of higher plant acids (Quénéa et al., 2004). Our results demonstrate that the effects of land use in the composition of fatty acids are most noticeable in topsoil in the deeper layers. Pedogenic processes and the interaction of the lipid fraction with the mineral phase are also important in order to study the decomposition of soil organic matter along the soil profile.

The aliphatic hydrocarbons are mainly $n$-alkanes in the $\mathrm{C}_{14}-\mathrm{C}_{35}$ range with a bimodal distribution (Figure 3). The long chain compounds in the $\mathrm{C}_{23}-\mathrm{C}_{35}$ range exhibit an odd-over-even $\mathrm{C}$ number. This pattern distribution was previously found in soils (Amblès et al., 1989; Bull et al., 1998). The predominance of the odd-carbon-numbered long-chain $n$-alkanes indicates a typical contribution from higher plant waxes; the short-chain C-compounds are commonly used as bacterial biomarkers (Moucawi et al., 1981; Amblès et al., 1989; Tan, 2003).
Several authors have frequently used the alkanoic acids $\mathrm{C}_{15: 0}$ and $\mathrm{C}_{17: 0}$ as biomarkers for soil bacteria (Vestal and White, 1989; Tunlid and White, 1992; Zelles et al., 1995). In both depths of $0-10 \mathrm{~cm}$ and $60-100 \mathrm{~cm}$, there is greater bacterial activity in the forest soil profile, as compared to tillage systems (Figure 2). This suggests that there may be differences in the microbial community composition with soil use changes.

The differences in the n-fatty acids and n-alkanes distributions in relation to soil uses (mainly at $0-10 \mathrm{~cm}$ ) (Figures 2 and 3) indicates that variations in soil lipid composition is associated with vegetation type. The extract of forest soil samples was richer in n-alkanoic acids than in cultivated soil samples (Table 2), showing that the relative distributions of $\mathrm{n}$-alkanoic acids was influenced by land use. We found a strong odd-chain signal in the relative distributions of $n$-alkanes from vegetation $\left(\mathrm{C}_{15}{ }^{-} \mathrm{C}_{35}\right)$. In extractable lipids from forest and coffee litter, $\mathrm{C}_{29}$ and $\mathrm{C}_{31}$ were predominant, while $\mathrm{C}_{31}$ and $\mathrm{C}_{33}$ compounds prevailed in the pasture litter. The $\mathrm{C}_{29}, \mathrm{C}_{31}$ and $\mathrm{C}_{33}$ distribution along the soil profile evidence a clear vegetation (litter) contribution concerning n-alkanes. In the soil under pasture, a higher contribution of the homologue $\mathrm{C}_{31}$ is observed, whereas in the soil under coffee the $\mathrm{C}_{29}$ is more abundant. The dominance of $\mathrm{C}_{31} \mathrm{n}$-alkanes observed (at $0-10 \mathrm{~cm}$ ) can be indicative of an important contribution by (grass) roots (Naafs et al., 2004). However, in this study, it is possible that n-alkanes compounds at $60-100 \mathrm{~cm}$ depth in soil under pastures do not originate directly from present grass vegetation, but from previous (40-50 years ago) forest cover. Likewise, the proportion of $\mathrm{C}_{31} \mathrm{n}$-alkanes in the area under coffee culture
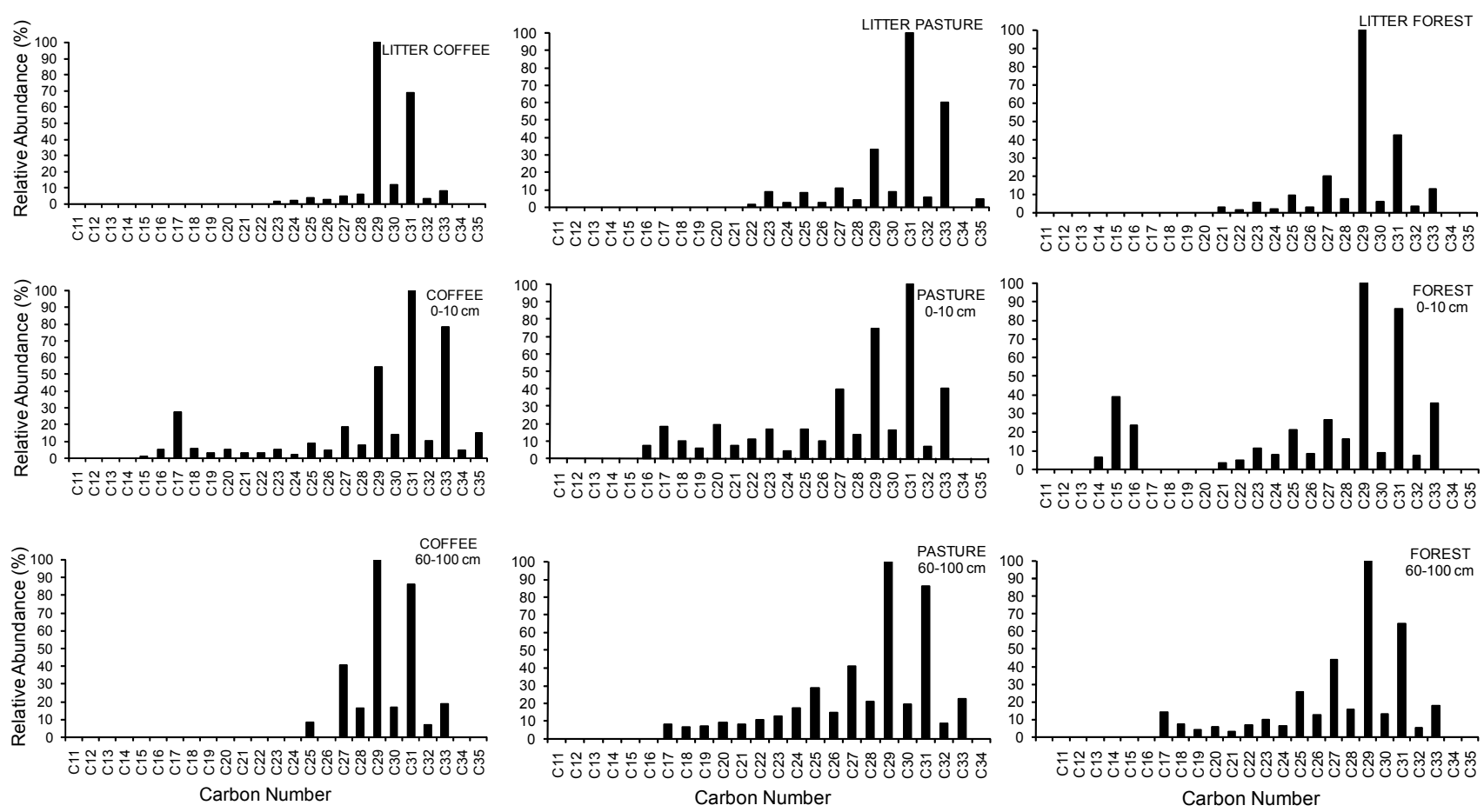

Figure 3 - Relative distributions of $n$-alkanes extracted from litter and soils analysed, normalized to the most abundant compound. 
Table 2 - Semi-quantitative analysis of main compounds of soil and litter lipids extractable of humic Oxisol under coffee, pasture and natural forest. (Percentage of total peak area of the chromatogram and the rations values).

\begin{tabular}{|c|c|c|c|c|c|c|c|c|c|}
\hline \multirow{2}{*}{ Compounds } & \multicolumn{3}{|c|}{ Coffee } & \multicolumn{3}{|c|}{ Pasture } & \multicolumn{3}{|c|}{ Forest } \\
\hline & Litter & $0-10^{\mathrm{a}}$ & $60-100^{\mathrm{a}}$ & Litter & $0-10^{\mathrm{a}}$ & $60-100^{a}$ & Litter & $0-10$ & $60-100$ \\
\hline Saturated n-alkanoic acids & 66.36 & 64.20 & 51.45 & 59.31 & 49.14 & 56.43 & 33.45 & 65.63 & 63.91 \\
\hline Unsaturated alkanoic acids & 11.42 & 1.85 & 1.51 & 29.74 & 8.45 & 0.71 & 15.50 & 15.65 & 4.48 \\
\hline n-Alkanols & 2.99 & 4.21 & 9.26 & 0.97 & 6.22 & 4.23 & 2.53 & 2.51 & 5.65 \\
\hline$n$-Alkanes & 3.74 & 3.27 & 14.07 & 3.03 & 2.88 & 15.04 & 31.61 & 2.31 & 7.17 \\
\hline$n$-Aldehy des & 3.36 & 1.09 & 1.58 & - & 2.80 & 0.88 & 0.40 & 0.06 & 3.27 \\
\hline$n$-Ketones & 1.94 & - & 3.44 & 1.87 & 0.21 & 1.66 & 0.39 & 0.47 & 2.64 \\
\hline Other Compounds & 10.19 & 27.24 & 18.69 & 5.08 & 30.30 & 21.05 & 16.12 & 13.37 & 12.88 \\
\hline \multicolumn{10}{|l|}{ Rations Values } \\
\hline n-Alkanoic $\mathrm{C}_{20+} / \mathrm{C}_{20-}$ & 0.04 & 1.20 & $\mathrm{C}_{20+} / \mathrm{nd}$ & 0.07 & 0.10 & 3.40 & 0.12 & 0.37 & 2.30 \\
\hline$n$-Alkanes $\mathrm{C}_{20+} / \mathrm{C}_{20-}$ & $\mathrm{C}_{20+} / \mathrm{nd}^{\mathrm{b}}$ & 7.20 & $\mathrm{C}_{20+} / \mathrm{nd}$ & $\mathrm{C}_{20+} / \mathrm{nd}$ & 4.10 & 10.76 & $\mathrm{C}_{20+} / \mathrm{nd}$ & 1.90 & 10.00 \\
\hline$n$-Ketones/n-Alkanes & 0.51 & - & 0.24 & 0.62 & 0.07 & 0.11 & 0.01 & 0.20 & 0.37 \\
\hline
\end{tabular}

${ }^{a}$ Depht in $\mathrm{cm}$; ${ }^{\mathrm{b}}$ no detected.

shows preservation this compound, probably originated from the grassy vegetation that covered the area 12 years before its use for coffee culture. In the most conservative systems like pasture and forest, shorter chain $n$-alkanes are the better preserved at greated depth (Figure 3).

The silylated lipid fractions revealed the presence of $\mathrm{n}$-alkanols in the samples from litter and soil, and their accumulation in depth (Table 2). These n-alkanols are present in epicuticular waxes and commonly observed in soil lipids (Van Bergen et al., 1997; Quénéa et al., 2004). In the case of soil under pasture, n-alkanols were preferentially preserved at soil surface in comparison to soil under coffee and forest. While the lipid composition of litter on pasture has lower n-alkanols content, it is possible that the root system contributes to the addition of these lipids in the topsoil.

The increase in free n-ketones at $60-100 \mathrm{~cm}$ may indicate changes of these compounds down the soil profile. The $\mathrm{n}$-ketones in the soil may be a result of oxidation products of n-alkanes (Quénéa et al., 2004) and/or of direct input from plant material (Bai et al., 2006), but a mechanism responsible for the genesis of these compounds in situ in the soil has not yet been elucidated. Nevertheless, Jansen and Nierop (2009) observed that in the volcanic ash soils longer chain n-ketones are the primary degradation product of the corresponding $n$-alkanes. Our results showed a concomitant increase of $n$ alkanes and $n$-ketones at a depth of $60-100 \mathrm{~cm}$ for coffee and forest (Table 2), thus may be possible that most of the ketone compounds in these systems derive from the oxidation of alkanes.

\section{Conclusions}

The differences in lipid content and composition between the forest, pasture and coffee culture can be as- cribed to differences in input of fresh organic materials. The lipid composition of soil and litter can be used as biomarkers in assessing changes in land use, as well as the occurrence of $\mathrm{C}$ stabilization mechanisms involving non humified alkylic material (waxes) in the dark soil layers of humic Oxisols at $60 \mathrm{~cm}$ or more in the soil profile.

\section{Acknowledgements}

To The National Council for Scientific and Technological Development $(\mathrm{CNPq})$ and The State of Minas Gerais Research Foundation (FAPEMIG), Brazil. To Trinidad Verdejo (IRNAS-CSIC), for the excellent technical assistance, and Dr. Jose Maria de la Rosa, for his advice and improving English in this paper.

\section{References}

Ahangar, A.G.; Smernik, R.; Kookana, R.S.; Chittleborough, D.J. 2009. The effect of lipids on the sorption of diuron and phenanthrene in soils. Chemosphere 74: 1062-1068.

Almendros, G.; Guadalix, M.E.; González-Villa, F.J.; Martin, F. 1996. Preservation of aliphatic macromolecules in soil humin. Organic Geochemistry 24: 651-659.

Almendros, G.; Tinoco, P.; González-Vila, F.J.; Lüdemann, H.D.; Sánz, J.; Velasco, F. 2001. ${ }^{13} \mathrm{C}-\mathrm{NMR}$ of forest soil lipids. Soil Science 166: 186-196.

Andrade, F.V.; Schaefer, C.E.G.R.; Correa, M.L.T.; Mendonça, E.S. 2004. Carbon stocks in Brazilian Latosols (oxisols) from different morphoclimatic regions and management systems. Communications in Soil Science and Plant Analysis 35: $2125-$ 2136

Bull, I.D.; Van Bergen, P.F.; Poulton, P.R.; Evershed, R.P. 1998. Organic geochemical studies of soils from the Rothamsted classical experiments. II. Soils from the Hoosfield Spring barley experiment treated with different quantities of manure. Organic Geochemistry 28: 11-26.

Bull, I.D; Van Bergen, P.F; Nott, C.J; Poulton, P.R; Evershed, R.P. 2000. Organic geochemical studies of soils from the Rothamsted classical experiments-V. The fate of lipids in different long-term experiments. Organic Geochemistry 31: 389-408. 
Chefetz, B.; Tarchitzky, J.; Deshumukh, A.P.; Hatcher, P.G.; Chen, Y. 2002. Structural characterization of soil organic matter and humic acids in particle-size fractions of on agricultural soil. Soil Science Society of America Journal 66: 129-141.

Dinel, H.; Schnitzer, M.; Mehuys, G. 1990. Soil lipids: origin, nature, content, decomposition and effect on soil physical properties. p. 397-430. In: Bollag, J.M.; Stotzky, G., eds. Soil biochemistry. Marcel Dekker, New York, NY, USA. v. 6

Feng, X.; Xu, Y.; Jaffé, R.; Schlesinger, W.H.; Simpson, M. 2010. Turnover rates of hydrolysable aliphatic lipids in Duke Forest soils determined by compound specific ${ }^{13} \mathrm{C}$ isotopic analysis. Organic Geochemistry 41: 573-579.

Jandl, G.; Leinweber, P.; Schulten, H.; Eusterhues, K. 2004. The concentrations of fatty acids in organo-mineral particle-size fractions of a Chernozem. European Journal of Soil Science 55: 459-469.

Jandl, G.; Leinweber, P.; Schulten, H. R.; Ekschmitt, K. 2005. Contribution of primary organic matter to the fatty acid pool in agricultural soils. Soil Biology \& Biochemistry 37: 1033-1041.

Jandl, G.; Leinweber, P.; Schulten H. R. 2007. Origin and fate of soil lipids in a Phaeozem under rye and maize monoculture in Central Germany. Biology Fertility Soils 43: 321-332.

Jansen, B.; Nierop, K.G.J.; Hageman, J.A.; Cleef, A.M.; Verstraten, J.M. 2006. The straight-chain lipid biomarker composition of plant species responsible for the dominant biomass production along two altitudinal transects in the Ecuadorian Andes. Organic Geochemistry 37: 1514-1536.

Jansen, B.; Nierop, K.G.J. 2009. Methyl ketones in high altitude Ecuadorian Andosols confirm excellent conservation of plantspecific n-alkane patterns. Organic Geochemistry 40: 61-69.

Ker, J.C. 1999. Latosols (Oxisols) of Brazil: a review. Genomos 5: 17-40. (in Portuguese, with abstract in English).

Instituto Brasileiro de Geografia e Estatística [IBGE] 1993. Vegetation map of Brazil. Rio de Janeiro. Available at: http:// www.ibge.gov.br/home/geociencias. [Accessed Ago. 08, 2007]. (in Portuguese).

Moucawi, J.; Fustec, E.; Jambu, P. 1981. Decomposition of lipids in soils: free and esterified fatty acids, alcohols and ketones. Soil Biology \& Biochemistry 13: 461-468.

Naafs, D.F.W.; Van Bergen, P.F.; Boogert, S.J.; Leeuw, J.W. 2004. Solvent-extractable lipids in an acid andic forest soil; variations with depth and season. Soil Biology \& Biochemistry 36: $297-$ 308.

Nierop, K.G.J.; Naafs, D.F.W.; Van Bergen, P.F. 2005. Origin, occurrence and fate of extractable lipids in Dutch coastal dune soils along a pH gradient. Organic Geochemistry 36: 555-566.

Quénéa, K.; Derenne, S.; Largeau, C.; Rumpel, C.; Mariotti, A. 2004. Variation in lipid relative abundance and composition among different particle size fractions of a forest soil. Organic Geochemistry 35: 1355-1370.
Quénéa, K; Derenne, S; González-Villa, F.J; González-Pérez, J.A; Mariotti, A.; Largeau, C. 2006. Double-shot pyrolysis of the non-hydrolysable organic fraction isolated from a sandy forest soil (Landes de Gascogne, South-West France) Comparison with classical Curie point pyrolysis. Journal of Analytical and Applied Pyrolysis 76: 271-279.

Resende, M.; Lani, J.L.; Rezende, S.B. 2002. Atlantic forest pedosystems relevant views on sustainability. Revista Árvore 26: 261-269. (in Portuguese, with abstract in English).

Schulten, H.R.; Schnitzer, M. 1990. Aliphatics in soil organic matter in fine-clay fractions. Soil Science Society of American Journal 54: 98-105.

Tan, H.K. 2003. Humic Matter in Soil and the Environment: Principles and Controversies. Marcel Dekker, New York, NY, USA.

Tunlid, A.; White, D.C. 1992. Biochemical analysis of biomass community structure, nutritional status, and metabolic activity of microbial communities in soil. p. 229-262. In: Stotzky, D.G.; Bollag, J.M., eds. Soil biochemistry: Marcel Dekker, New York, NY, USA.

Van Bergen, P.F.; Bull, I.D.; Poulton, P.R.; Evershed, R.P. 1997. Organic geochemical studies of soils from the Rothamsted classical experiments. I. Total lipid extracts, solvent insoluble residues and humic acids from Broadbalk Wilderness. Organic Geochemistry 26: 117-135.

Vestal, J.R.; White, D.C. 1989. Lipid analysis in microbial ecology. Bioscience 39: 535-541.

Weisenber, G.L.B.; Schwark, L. 2006. Carboxylic acid distribution patterns of temperate $\mathrm{C}_{3}$ and $\mathrm{C}_{4}$ crops. Organic Geochemistry 37: 1973-1982.

Weisenberg, G.L.B; Dorodnikov, M.; Kuzyakov, Y. 2010. Source determination of lipids in bulk soil and soil density fractions after four years of wheat cropping. Geoderma 156: 267-277.

Zelles, L.; Rackwitz, Q.Y.; Baibeck, T.; Beese, F. 1995. Discrimination of microbial diversity by fatty acid profiles of phospholipids and lipopolysaccharides in differently cultivated soils. p. 115-122. In: Collins, H.P.; Robertson, G.P.; Klug, M.J., eds. The significance and regulation of soil biodiversity. Kluwer: Academic, New York, NY, USA.

Ziegler, F.; Zech, W. 1989. Distributon patern of total lipids fractions in forest humus. Journal of Plant Nutrition and Soil Science 152: 287-290.

Received November 05, 2009

Accepted October 05, 2010 